\title{
ENHANCEMENT OF Pseudomonas flourescense WITH CERTAIN MICROELEMENTS FOR CONTROLLING MAIZE STALK ROT CAUSED BY Fusarium verticilliodes (SACC.) UNDER GREENHOUSE CONDITIONS \\ Eraky, Amal M. I. * and Hala H. Gomaa ${ }^{* *}$ \\ "Plant Pathology Dept., Fac. Agric., Assiut University, Assiut, Egypt. \\ "Water and Soil Dept., Fac. Agric., Assiut University, Assiut, Egypt.
}

\begin{abstract}
F. verticilliodes (Sacc.) Nirenberg $(G)$ is the major pathogen of maize worldwide causing seedling, stalk and ear rots. Five isolates of $F$. verticilliodes have ability to infect maize Pioneer cultivar plants. The isolates varied in their infectivity, $F$. verticilliodes isolate 3 gave the highest stalk rot severity in both 2008 and 2009 growing seasons, followed by isolate 4 , while isolate 5 was the lowest pathogenic one. In vitro, the microelements [zinc ( $\mathrm{Zn})$, manganese $(\mathrm{Mn})$ and copper $(\mathrm{Cu})$ ] reduced linear growth of the pathogen. Manganese exhibited the highest toxic effect followed by zinc while, copper exhibited the lowest toxic effect. The antagonistic effects of $3 P$. fluresences isolates on mycelial growth of $F$. verticilliodes were in the range of 55.14 to $79.82 \%, P$. fluresences isolate (Pf2) considerably more antagonistic than other isolates. Under greenhouse conditions, treatment of maize plants with microelements decreased significantly disease severity. Manganese treatment was more effective than copper and zinc treatments. The biocontrol with $P$. fluresences (Pf2) provided moderate level of protection when used alone, while combination of Pf2 with microelements treatment significantly improved the biocontrol activity and significantly reduced disease severity compared with microelements alone. Microelements content increased with $P$. fluresences treatment comparing with control treatment.
\end{abstract}

\section{INTRODUCTION}

Maize (Zea mays $L$ ) is attacked by several diseases. Fusarium stalk rot of maize caused by $F$. verticilliodes, represents the common stalk rot in many areas of the world such as Egypt. Management of Fusarium stalk rot has little success with classical methods as fungicides. There is a serious need for alternative control. Among different suggestions, there is an increasing interest in the introduction of bacterial and fungal biocontrol agent for managing different pathogens to avoid using chemical fungicides and their side effect on human health and environment. Rhizospheric Pseudomonas fluorescent bacterium has used in the biological control of plant diseases because of several advantages compared to other biocontrol agents.

Different mechanisms are involved to interrupt the importance of plant growth-promoting (PGP) rhizobacteria, one of them is induction of resistance (Geels and Schippers, 1983, Fravel 1988 and Weller, 1988). It has been demonstrated that the rhizospheric bacteria like pseudomonads stimulate the growth of shoot and roots of different plants (Arndt et al., 1998). Plant growth promoting bacteria, Pseudomonas spp. can suppress pathogenic strains of $F$. oxysporum by sidrophore-mediated competition (Van 
Peer et., al.1990, Lemanceau et al., 1992, Duijff et. al., 1993 and Zhou and Paulitz, 1994). Pure culture of $P$. fluorescens used as seed treatment and as spray treatment enhanced the growth parameters and reduced the incidence of $F$. verticillioides compared with the other treatments (Nayaka et. al., 2009,).

Also using of microelements, such as manganese and zinc, for inducing resistance is an alternative method, (Marschner, 1986, Abd El-Hai et. al., 2007 and El Baz, 2007). An adequate supply of manganese and several other microelements are important in most of active defense mechanisms mediated through the shikimate pathway.

This work was planned to study enhancement of flouresent bacterium (Pseudomonas fluoresences) with certain microelements ( $\mathrm{Cu}, \mathrm{Mn}$ and $\mathrm{Zn}$ ) for controlling Fusarium stalk rot of maize.

\section{MATERIALS AND METHODS}

\section{Source of organisms:}

$F$. verticilliodes and $P$. fluresences isolates were supplied from stock culture of Plant Pathology Dept., Faculty of Agriculture, Assiut University.

Maize cultivar (Pioneer) was, kindly, supplied from Agriculture research center, Giza, Egypt.

\section{Pathogenicity test:}

$F$. verticilliodes isolates were examined for their pathogenicity of stalk rot on the corn cultivar Pioneer under greenhouse conditions in the corn growing seasons 2008 and 2009. For inoculation of stalks, the toothpick technique was used as described by Jardine and Leslie (1992). Round wooden toothpicks about $6 \mathrm{~cm}$. long were boiled several times (about $1 \mathrm{hr}$. each time) in tap water to remove any possible toxic substances that might inhibit the growth of the tested fungi. Boiled toothpicks were washed in fresh tap water after each boiling, then dried and packed into glass jars. Potato dextrose broth, supplemented with $0.1 \%$ yeast extracts was added to moisten the toothpicks until slight excess of the medium accumulated at the bottom of each jar and autoclaved immediately at $1.5 \mathrm{~cm}^{2}$ for $20 \mathrm{~min}$. Autoclaved toothpicks were inoculated with $8 \mathrm{~mm}$. in diameter discs of $F$. verticilliodes cultures and incubated at $27{ }^{\circ} \mathrm{C}$ about 3 weeks until the fungal growth covered the toothpicks.

Five of surface sterilized grains of the tested cultivar (pioneer) were sown in sterilized pots $(30 \mathrm{~cm}$. in diameter), containing autoclaved soil. Inoculation was performed at second internode from the ground surface of forty days old plants by using an ice pick to create a hole at the second internode. A toothpick was then inserted into the hole. Sterile toothpicks were inserted into the second internode of control plants. One month after inoculation, the stalks were cut longitudinally and stalk discoloration was determined using the following rating scale ranging from 1 to 5 (Hooker, 1956): $1=0-25 \%, 2=26-50 \%, 3=51-75 \%, 4=76-100 \%$ of the inoculated internode diseased and $5=100 \%$ with infection extending into the adjacent internode. For each replicate a disease index (DI) similar to that described by Liu et al. (1995) was calculated as follows: $\mathrm{Dl} \%=\sum(1 \mathrm{~A}+2 \mathrm{~B}+3 \mathrm{C}+4 \mathrm{D}+5 \mathrm{E}) /$ 
5T X 100 where, A, B, C and D are the number of plants corresponding to the numerical grade, $1,2,3,4$ and 5 , respectively, and $5 \mathrm{~T}$ is the total number of plants $(T)$ multiplied by the maximum discoloration grade 5 .

In vitro experiments:

Effect of certain microelements on the fungal linear growth:

To study the effect of manganese, zinc and copper at 100, 200,300, and $400 \mathrm{ppm}$ it were separately mixed in PDA medium before solidification, and then poured in sterile Petri dishes $(9 \mathrm{~cm})$. Five plates for each treatment were used as replicates, while each plate was inoculated with $5 \mathrm{~mm}$ fungal disc and incubated at $25^{\circ} \mathrm{C}$. The linear growth of the fungus was measured when the full growth of tested isolate was observed in the check treatment and the average growth diameters were calculated. The experiment was carried out twice.

Antagonistic effect of different $P$. fluoresences isolates on the pathogenic fungus:

This study was in the Plant Pathology Dept., Faculty of Agriculture, Assiut University. Agar disks carrying mycelium of $F$. verticilliodes, each was placed at the centre of PDA plate between two parallel streaks of the tested bacteria (3 isolates of Pseudomonas were tested), which were $5 \mathrm{~cm}$ apart. Plates inoculated with the fungus alone served as control, when the fungal growth of the control approached the edge of the plates. In vitro antagonistic effect was assessed by relating mycelial diameter on plates inoculated with bacteria to mycelial diameter on control plates and computing inhibition percentages. Five plates were used for each treatment. The experiment was carried out twice.

\section{Preparation of $\boldsymbol{P}$. fluoresences inoculum:}

Pseudomonas isolate (Pf2) of the $48 \mathrm{~h}$-old-culture in Kings medium B was centrifuged at $10.000 \mathrm{rpm}$ for $10 \mathrm{~min}$. Pellets (bacterial cells) were washed twice with sterilized distilled water by centrifugation. The optical density of the solution was adjusted to 0.45 (A610 nm) to obtain $10{ }^{8} \mathrm{CFU} / \mathrm{ml}$ with the help of a UV-Visible spectrophotometer.

Effect of certain microelements and $P$. fluoresences (Pf2) on disease severity:

Under greenhouse conditions in 2009 and 2010 maize growing season, surface sterilized grains of Pioneer cultivar were sown in sterilized pots $(30 \mathrm{~cm}$ in diameter) containing sterilized soil. After forty days, toothpick technique was used for inoculating F. verticilliodes isolate F3 (the highly virulent isolate) as mentioned above. Plants were sprayed with Pseudomonas at concentration of $10^{8} \mathrm{CFU} / \mathrm{ml}$ after 45 days from planting then sprayed with $\mathrm{Zn}$ (as EDTA), Cu (as $\mathrm{CuSO}_{4}$ ), and $\mathrm{Mn}$ (as EDTA) separately at concentration of $300 \mathrm{ppm}$. The same treatments were repeated after 60 days from planting. Plants not inoculated with Pseudomonas served as control. Normal NPK was applied as recommended and the plants were irrigated when necessary. Disease severity was assessed as disease index as mentioned in pathogenicity tests experiment.

Analysis of microelements in plants:

At the end of the seasons, leaves samples were collected and washed with tap water and then with deionized water three times. After that, 
the leaves samples were dried at $70^{\circ} \mathrm{C}$ for 48 hours in electric oven. The oven dried leaves samples were grinded properly in mortar with pestle to make it homogenous and 0.5 gram of sample was treated with a $2: 1 \mathrm{HNO}_{3}$ : $\mathrm{HClO}_{4}$ acid mixture until the solution became clear (Usman and Mohamed, 2009). Digested samples were filtered using filter papers and made up to 50 $\mathrm{mL}$ with $\mathrm{HNO}_{3}$. Four replicates from each treatment were used in this experiment. $\mathrm{Mn}, \mathrm{Zn}$ and $\mathrm{Cu}$ were determined with a GBC Model 906 atomic absorption spectrophotometer (AAS) from digestion solution mined volumetrically by EDTA (versene) method (Page et al., 1982).

Statistical analysis:

All data were subjected to statistical analysis and means were compared using L.S.D. range test as described by Gomez and Gomez, 1984.

\section{RESULTS}

\section{Pathogenicity tests:}

The pathogenicity test showed that five isolates of $F$. verticilliodes have ability to infect maize pioneer cultivar (Table 1). $F$. verticiliodes isolates varied in their infectivity on maize plants. Data show that $F$. verticiliodes F. 3 gave the highest stalk rot severity in both 2009 and 2010 growing seasons, followed by F. 4 isolate, then F. 1 isolate, while, F. 5 isolate was the least pathogenic one.

Table (1): Index of stalk rot disease on maize plants caused by the tested $\boldsymbol{F}$. verticiliods isolates

\begin{tabular}{|l|c|c|}
\hline \multirow{2}{*}{ F. verticilliodes isolate } & \multicolumn{2}{|c|}{ Disease index \% } \\
\cline { 2 - 3 } & 2008 growing season & 2009 growing season \\
\hline F. I & 28.33 & 30.66 \\
F.2 & 22.66 & 23.33 \\
F.3 & 52.75 & 49.50 \\
F.4 & 37.20 & 36.33 \\
F.5 & 19.75 & 20.33 \\
Control & 0.00 & 0.00 \\
\hline L.S.D. at $P \leq 0.05$ & $\mathbf{1 6 . 5 0}$ & $\mathbf{1 4 . 2 0}$ \\
\hline
\end{tabular}

\section{Effect of certain microelements on fungal linear growth}

Data in Table 2 show inhibitory effect of zinc, manganese and copper on mycelial linear growth of the pathogen. In general, all tested microelements reduced linear growth of $F$. verticilliodes in vitro. Mn exhibited the highest toxic effect followed by zinc. Cu exhibited the lowest toxic effect on $F$. verticiliodes. Microelements concentrations varied in their toxic effect, in which, 400 and $300 \mathrm{ppm}$ exhibited the highest reduction of mycelial growth followed by $200 \mathrm{ppm}$, at $100 \mathrm{ppm}$, the lowest toxic concentration of the tested microelements was obtained. Data also indicated that there is no significant difference between 300 and 400 ppm. 
Table (2): Reduction percent in mycelial growth of $F$. verticiliodes influenced by different concentrations of some microelements.

\begin{tabular}{|l|c|c|c|c|c|}
\hline \multirow{2}{*}{ Microelement } & \multicolumn{3}{|c|}{ Microelement concentration (ppm) } & \multirow{2}{*}{ Mean } \\
\cline { 2 - 5 } & $\mathbf{1 0 0}$ & $\mathbf{2 0 0}$ & $\mathbf{3 0 0}$ & $\mathbf{4 0 0}$ & \\
\hline $\mathrm{Zn}$ & 45.50 & 55.20 & 70.30 & 71.50 & $\mathbf{6 0 . 6 3}$ \\
$\mathrm{Mn}$ & 55.90 & 58.70 & 70.10 & 72.50 & $\mathbf{6 4 . 3 0}$ \\
$\mathrm{Cu}$ & 20.80 & 28.60 & 33.70 & 35.60 & $\mathbf{2 9 . 6 8}$ \\
Control & 0.00 & 0.00 & 0.00 & 0.00 & $\mathbf{0 . 0 0}$ \\
\hline Mean & $\mathbf{3 0 . 5 5}$ & $\mathbf{3 5 . 6 3}$ & $\mathbf{4 3 . 5 3}$ & $\mathbf{4 4 . 9 0}$ & \\
\hline
\end{tabular}

L.S.D. (PS0.05) ; Microelements (A): 4.12 Concentration (B) 5.66 Interaction (AxB) 7.12

\section{Antagonistic effect of $P$. flourescense isolates on fungal mycelial growth In vitro}

The inhibitory effect of Pseudomonas flourescense isolates on mycelial growth of Fusarium verticilliodes was shown in Figure (1). Results indicate that the 3 isolates gave positive reaction of antagonism to the pathogen in vitro. The antagonistic effects of $P$. flourescense against $F$. verticiliodes were in the range of $55.14-79.82 \%$. P. flourescense (Pf2) considered more antagonistic to $F$. verticilliodes than the other isolates. $P$. flourescense Pf2 isolate gave the highest effect (79.82) followed by Pf3 isolate (59.2) and then Pf1 isolate (55.14).

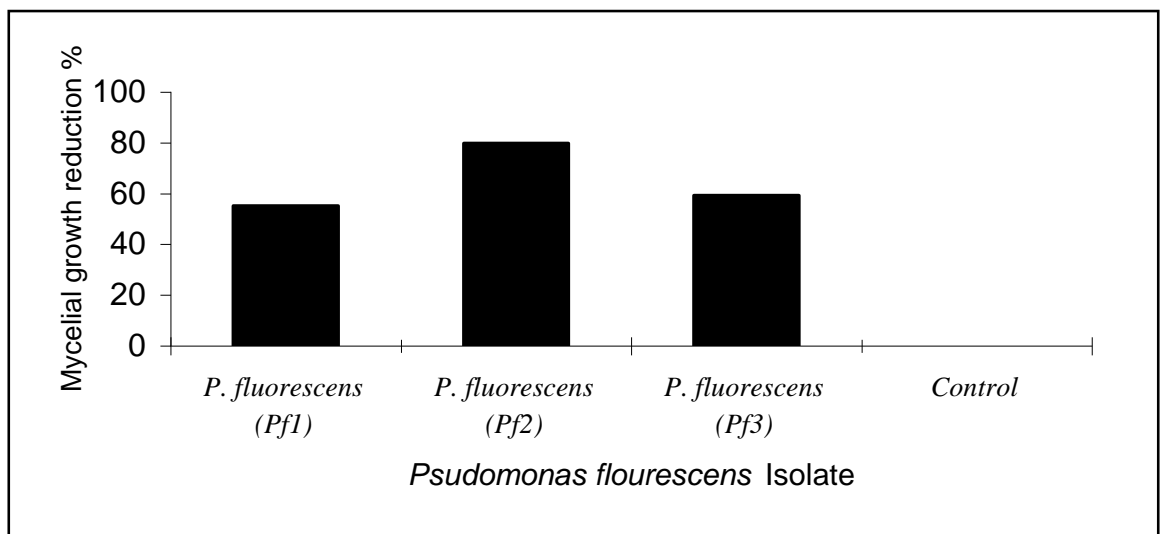

Figure (1): Antagonistic effect of $P$. flourescense isolates on linear growth of $F$. verticilliodes

\section{Effect of tested microelements and $P$. flourescense $(\mathrm{Pf} 2)$ biocontrol on disease incidence}

Results in Table (3) indicate that treatment of maize plants with 300 $\mathrm{ppm} \mathrm{Cu}, \mathrm{Mn}$ and $\mathrm{Zn}$ decreased significantly disease severity. Manganese treatment was more effective than copper and zinc treatments. The bioicontrol agent (Pf2) isolate provided a moderate level of protection, reducing disease index from 58.50 to $29.67 \%$ and from 65.00 to $42.31 \%$ in 2010 and 2011, maize growing seasons, respectively. Combination of Pf2 with minerals significantly reduced disease severity compared with the minerals alone. The combination between Pf2 and zinc was more effective in 
this respect than zinc only in two experimental seasons followed by combination between Pf2 and manganese treatment. .

Table (3): Effect of certain microelements and $P$. flourescens (Pf2) on maize stalk rot disease under greenhouse conditions in 2010 and 2011 maize growing seasons

\begin{tabular}{|l|c|c|c|c|}
\hline \multirow{2}{*}{ Treatment } & \multicolumn{2}{|c|}{ 2010 growing season } & \multicolumn{2}{c|}{ 2011 growing season } \\
\cline { 2 - 5 } & Disease index \% & Reduction \% & Disease index \% & Reduction \% \\
\hline $\mathrm{Cu}$ & 28.83 & 50.71 & 39.42 & 39.35 \\
$\mathrm{Mn}$ & 16.25 & 72.22 & 36.09 & 44.48 \\
$\mathrm{Zn}$ & 35.20 & 39.83 & 40.67 & 37.43 \\
$\mathrm{P}$. flourescens (Pf2) & 29.67 & 49.28 & 37.50 & 42.31 \\
$\mathrm{Pf2}+\mathrm{Cu}$ & 22.42 & 61.67 & 33.50 & 48.46 \\
$\mathrm{Pf} 2+\mathrm{Mn}$ & 13.50 & 76.92 & 30.00 & 53.85 \\
$\mathrm{Pf2}+\mathrm{Zn}$ & 16.92 & 71.08 & 18.09 & 72.17 \\
Control & 58.50 & - & 65.00 & - \\
\hline \multicolumn{1}{|c|}{ L.S.D. at $P \leq 0.05$} & 5.60 & & 6.72 & \\
\hline
\end{tabular}

Microelements contents in maize leaves

$\mathrm{Cu}, \mathrm{Mn}$ and $\mathrm{Zn}$ contents in leaves of maize plants were determined as $\mathrm{mg} / \mathrm{Kg}$ fresh weight. Results in Table (4) indicate that the copper and zinc contents in the leaves of the treated plants with $P$. flourescens (Pf2) were significantly higher than those of manganese compared with untreated plants (control) in the both experimental seasons.

Table (4): Content of microelements $(\mathrm{mg} / \mathrm{Kg}$ fresh weight) in maize leaves as affected by $P$. flourescens (Pf2)

\begin{tabular}{|l|r|r|r|r|r|r|}
\hline \multirow{2}{*}{ Treatment } & \multicolumn{2}{|c|}{ Cu } & \multicolumn{2}{c|}{ Mn } & \multicolumn{2}{c|}{ Zn } \\
\cline { 2 - 7 } & $\mathbf{2 0 1 0}$ & $\mathbf{2 0 1 1}$ & $\mathbf{2 0 1 0}$ & $\mathbf{2 0 1 1}$ & $\mathbf{2 0 1 0}$ & $\mathbf{2 0 1 1}$ \\
\hline P. flourescens & 25.28 & 22.98 & 59.95 & 57.86 & 35.88 & 47.80 \\
Control & 19.03 & 11.64 & 55.05 & 53.95 & 25.31 & 39.88 \\
\hline L.S.D. 0.05 & $\mathbf{2 . 1 7}$ & $\mathbf{5 . 2 5}$ & $\mathbf{5 . 2 1}$ & $\mathbf{4 . 8 8}$ & $\mathbf{7 . 1 2}$ & $\mathbf{6 . 1 3}$ \\
\hline
\end{tabular}

\section{DISCUSSION}

F. verticillioides may cause seedling blight and stalk rot as well as ear rot on maize (Thomas and Buddenhagen, 1980; Asran and Aboul-Nasr, 2011). The results of this investigation revealed that all tested isolates able to infect maize plants and cause stalk rot disease. The isolates, however, varied considerably in disease severity. Bacon et al. (1996), Asran and Buchenauer (2002) and Asran and Aboul-Nasr (2011) also reported considerable variability in pathogenicity of $F$. verticillioides isolated to maize plants.

Microelement amendments have been used commercially on a limited scale to manage certain soil borne diseases including Fusarium diseases (Engelhard, 1989). Data in our investigation show that all tested microelements reduced growth of $F$. verticillioides in vitro. Manganese exhibited the highest toxic effect followed by zinc, while, copper exhibited the lowest toxic effect. Pathogen suppression, by using microelement, is most often attributed to direct inhibition of fungal growth and activity (Huber, 1989 and Asran 2012). 
Testing antagonistic capabilities of certain $P$. flourescens isolates was investigated in vitro. Data revealed that all the tested isolates were able to inhibit the mycelial growth of the pathogen with different degrees of antagonistic capability. Several researchers have successfully employed antagonistic bacteria to control plant diseases (Hassan and Abd El-Rehim, 2002 and Hussein et al., 2007).

Under greenhouse conditions, treatment of maize plants with 300 ppm copper, manganese and zinc decreased significantly disease index. Manganese treatment was more effective than copper and zinc treatments. Mandal and Sinha (1992) suggested that zinc and other minerals reduce Fusarium wilt of tomato by inducing host resistance. Disease reduction, by using microelement, is most often attributed to improve nutrition that boosts host defenses or to direct inhibition of fungal growth and activity. Pathogen suppression may result indirectly from modification of chemical and physical properties of soil and rhizosphere (Simon and Sivasithamparam, 1989) or from modification of host root exudates to disfavor pathogen activity (Huber, 1989).

Data herein show that the bioicontrol agent; $P$. flourescense (Pf2) provided a moderate level of protection when used alone. $P$. flourescense is a biocontrol agent with activity against diseases caused by soil borne fungal pathogens (Voisard et. al., 1994). We found that microelement significantly improved the biocontrol activity of $P$. flourescense (Pf2) against $F$. verticillioides. Zinc in combination with $P$. flourescense improve biocontrol of Fusarium crown and root rot of tomato and repress the production of pathogen metabolites (Duffy and Défago, 1997). There are a few cases, though, in which minerals appear to reduce disease e.g., exerting an indirect beneficial effect on indigenous and introduced antagonistic microorganisms (Elmer, 1995). Zinc soil content has been found to be positively correlated with the biocontrol activity of introduced $P$. flourescense 2-79 (Weller and Thomashow, 1994).

\section{REFERENCES}

Abd El-Hai, K.M., M. A. El-Metwally and S. M. El-Baz (2007). Alleviation of the damage of bean chocolate spot and rust diseases by some nutritional elements. J. Agric Sci., Mansoura Univ. 32: 8231 - 8243.

Arndt, W., C. Kolle, and H. Buchenauer (1998). Effectiveness of fluoredcent pseudomonas on cucumber and tomato plants under practical condetiond and preliminary studied on the mode of action of the antagonists. Z. PFIKrankh. PFLSchutz 105: $198-215$.

Asran, M. R. (2012). Effect of certain microelements on grain sorghum stalk rot caused by Fusarium moniliforme J. Sheld, J. Plant Prot. and Path. Mansoura Univ., 3: 23 -33.

Asran, M. R.. and M. B. Aboul-Nasr (2011). Virulence of Fusarium verticilliodes (SACC.) Nirenberg $(G)$ isolates on maize plants associated with fumonisins production, J. Plant Prot. And Path. Mansoura Univ., 2: $653-662$. 
Asran, M. R. and H. Buchenauer (2002). Virulence of Fusarium moniliforme isolates on maize plants in relation to fumonisin and ergosterol levels. Journal of Plant Disease and Protection, 109: 491-505.

Bacon, C. W., J. K. Porter, W. P. Norred, andJ. F. Leslie (1996). Production of fusaric acid by Fusarium species. Appl. Environ. Microbiol.. 62: 4039 -4043 .

Duffy, B. K. and G. Defago (1997). Zinc improves bioconontrol of Fusarium crown and root rot of tomato by Pseudomonad fluorescens and represses the production of pathogen metabolites inhibitory to bacterial antibiotic biosynthesis. Phytopathology, 87: 1250 - 1257.

Duijff, B. J., J. W. Meijer, P. A. H. M. Bakker and B. Schippers (1993). Siderophore-mediated competion for iron and induced resistance in the suppression of Fusarium wilt of carnation by fluorescent Pseudomonas spp. Neth, J. Plant Pathol. 99: $277-289$.

$\mathrm{El}-\mathrm{Baz}, \mathrm{S}$. M. (2007). Induction of resistance in some soyabean varieties against root rot diseases by some chemical inducers. Egypt. J. Applied Sci., 22: $68-80$.

Elmer, W. H. (1995) Association between Mn- reducing root bacteria and $\mathrm{NaCL}$ application in suppression of fusarium crown and root rot of asparagus. Phytopathol. 85: $1461-1467$.

Engelhard, A. W. (1989). Soil-borne Plant Pathogens: Management of diseases with macro- and microelements. The American Phytopathological Society, St. Paul, 217 pp.

Fravel, D. R. (1988). Role of antibiosis in the biocontrol of plant diseases. Annu. Rev. Phytopathol. 26: 75 - 91.

Geels, F. P., and B. Schippers. (1983). Selection of antagonistic fluorescent Pseudomonas spp. And their root colonization and persistence following treatment of seed potatoes. J. Phytopathol. 108: $193-206$.

Gomez, K. A. and A. A. Gomez (1984). Statistical procedures for Agriculture Research, $2^{\text {nd }}$ ed. John Willey. New York, $680 \mathrm{p}$.

Hassan, M. H. A. and G. H. Abd El-Rehim (2002). Yeast application as a biofertilizer and biocontrol agent for onion neck rot disease in relation to bulb productivity and quality. Assiut J. Agric. Sci. 33: $241-251$.

Hooker, A. L. (1956). Association of resistanve of several seedling, root, stalk, and ear diseases in corn. Phytopathology, 46: 175 - 176.

Huber, D. M. (1989). The role of nutrition in the take-all disease of wheat and other small grains. Pages 46-76 in: Soil-borne Plant Pathogens: Management of diseases with macro- and microelements. A. W. Engelhard, ed., The American Phytopathological Society, St. Paul, MN.

Hussein, M. A. M, M. H. A. Hassan, A. D. A. Allam, and K. A. M. Abo Elyouser (2007) Management of Stemphylium blight of onion by using biological agents and resistance inducers. Egypt. J. Phytopathol. 35: 49 -60 .

Jardine, D. J., J. F, Leslie (1992). Agressivenss of Gibberella fujikuroi (Fusarium moniliform) isolates to grain sorgum under greenhouse conditions. Plant Dis. 76: 897 - 900. 
Lemanceau, P., Bakker, P.A. M., De Kogel, W. J., Alabouvette, C., and B. Schippers (1992). Effect of pseudobacteria in 358 production by Pseudomonas putida WCS358 on suppression of Fusarium wilt of canations by nonpathogenic Fusarium oxysporum Fo47. Appl. Environ. Microbiol., 58: 2978 - 2982.

Liu, L., J. W. Klopper, and S. Tuzun (1995). Induction of systemic resistance against cucumber mosaic virus by seed inoculation with select rhizobacterial strains. (Abstr) Phytopathology 82: $1108-1109$.

Mandal, N. C., A. K. Sinha (1992). An alternative approach for the chemical control of fusarium wilt of tomato. Indian Phytopathol. 45: $194-198$.

Marschner, H. (1986). Mineral Nutrition of Higher Plants. Academic Press, London.

Nayaka, S. C., A. C. U. Shankar, M. S. Reddy,S. R. Niranjana, H. S. Prakash, H. S. Shettya and C. N. Mortensenc (2009). Control of Fusarium verticillioides, cause of ear rot of maize, by Pseudomonas fluorescens. Pest Manag Sci 2009; 65: 769-775.

Page, A. L., R. H. Miller, and D. R. Keeney (1982). Methods of soil analysis: Chemical and microbiological properties. Agronomy 9 (Part 2).Madison, WI:Am. Soc. Of Agon, Soil Sci. Soc.Am.

Simon, A., and K. Sivasithamparam (1989). Pathogen - suppression: A case study in biological suppression of Gaeumannomyces graminis var tritici in soil. Soil. Biol. Biochem. 21: $331-337$.

Thomas, D. and W. Buddenhagen (1980). Incidence and persistence of Fusarium moniliforme in symptomless maize kernels and seedling in Nigeria. Mycologia 72: $882-887$.

Usman A. R., and H M. Mohamed. (2009). Effect of microbial inoculation and EDTA on the uptake and translocation of heavy metal by corn and sunflower. Chemosphere 76 893-899.

Van Peer, R., A. J., H. Rattink, and B. Schippers. (1990) control of Fusarium wilt of carnation grown on rock wool by Pseudomonas sp. Strain wcs417R and FeEDDHA. Neth. J. Plant Pathology. 96: 119 - 132.

Voisard, C., C. T., Bull, C. Keel, J. Laville, M. Maurhofer, U. Schneider, G. Defeco and D. Hasas (1994). Biocontrol of root diseases by Pseudomonas fluoresens CHAO: Current concepts and experimental approaches. Molecular Ecology of Rhizosphere Microorganisms Pages $67-89$.

Weller, D. M. (1988). Biological control of soilborne plant pathogens in the rhizosphere with bacteria. Ann. Rev. Phytopathol. 26: $379-407$.

Weller, D. M., and L. S. Thomashow (1994). Current challenges in introducing beneficial microorganisms into the rhizosphere. in Molecular Ecology of Rhizosphere Microorganisms Pages 1 -18.

Zhou, T., and T. C. Paulitz (1994). Induced resistance in the biocontrol of pythium aphanidermatum by Pseudomonas spp. On cucumber. J. Phytopathol. 142: $51-63$. 


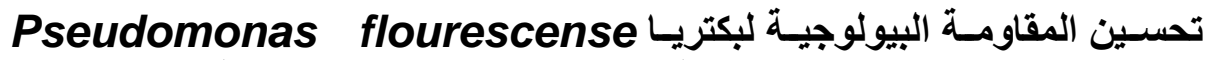
باستخذام العناصر الصغرى لمقاومـة عفن السـاق في الذرة الثـامية المتسبب عن

Fusarium verticilliodes الفطرئ

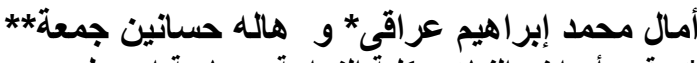

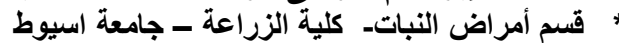

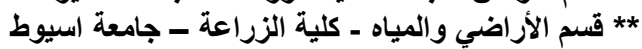

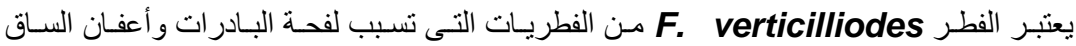

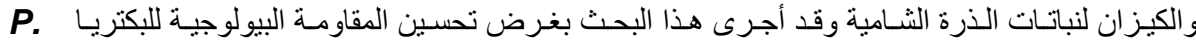
flourescense

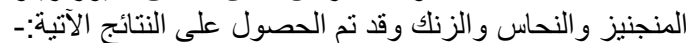

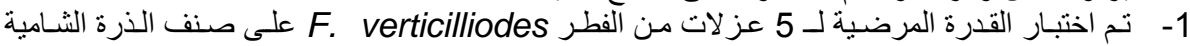

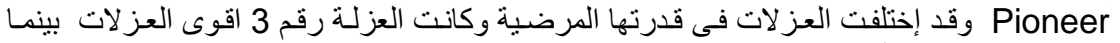

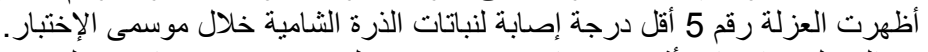

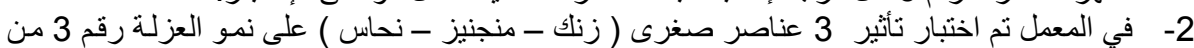

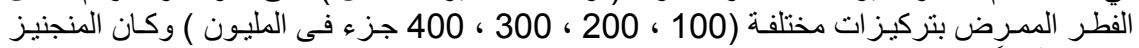

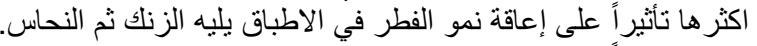

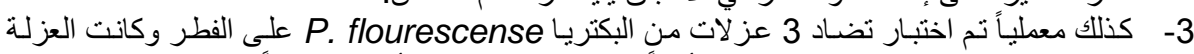

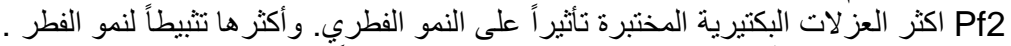

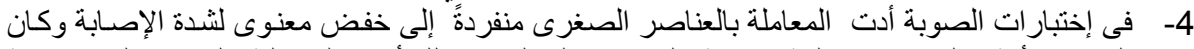

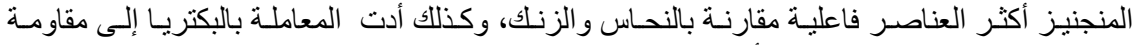

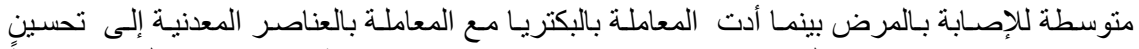

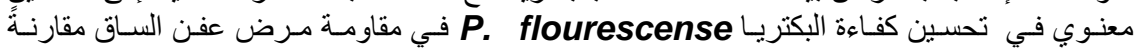
بإستخدام البكتريا منفردة أو إستخدام العناصر البكاب الغذائية كل على حده.

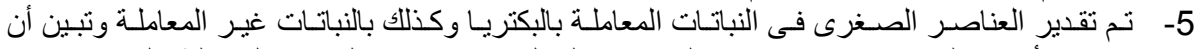

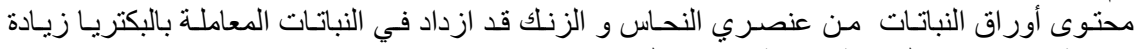

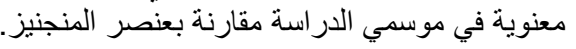

كلية الزراعة - جامعة المنصورة مركز البحوث الزراعية
قام بتحكيم البحث

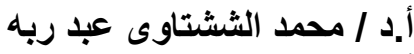
أ.د أد / مسام الدين اسماعيل على صابل ربه 